\title{
Salicylic acid immersion maintains physiochemical quality and enhances bioactive compounds in 'Kimju' guava fruit during cold storage
}

\author{
Suriyan Supapvanich ${ }^{*}$, Boonwat Mahasap², Panida Boonyaritthongchai ${ }^{3}$, Chairat Techavuthiporn ${ }^{4}$, \\ Racha Tepsorn ${ }^{4}$, Pannipa Youryon ${ }^{5}$ \\ ${ }^{1}$ Department of Agricultural Education, Faculty of Industrial Education and Technology, King Mongkut's Institute of Technology Ladkrabang, \\ Chalongkrung Rd., Ladkrabang, Bangkok, 10520, Thailand, ${ }^{2}$ Postharvest Technology Program, School of Bioresources and Technology, \\ King Mongkut's University of Technology Thonburi, Bangkok, Thailand, 'ivision of Biological Science, Faculty of Science and Technology, \\ Huachiew Chalermprakiet University, Samutprakarn, Thailand, ${ }^{4}$ Department of Food Science and Technology, Faculty of Science and \\ Technology, Thammasat University, Klong Luang, Prathumthani, Thailand, ${ }^{5}$ Department of Agricultural Technology Prince of Chomphon \\ campus, King Mongkut's Institute of Technology Ladkrabang, Pathiu District, Chomphon Province, 86160 Thailand
}

\section{A B S TR A C T}

The aims of this work were to investigate the effect of salicylic acid (SA) immersion on the physicochemical quality maintenance and biologically active compounds enhancement of 'Kimju' guava. The fruit were immersed in water (control) and 2 mM SA solution and stored at $12 \pm 1{ }^{\circ} \mathrm{C}, 90 \pm 2 \% \mathrm{RH}$. The observed factors were pigments, total sugars, total soluble solids (TSS), total acidity (TA), firmness and pectin components, bioactive compounds such as ascorbic acid (AsA), total phenols (TP), total flavonoids (TF) and the activities of antioxidant enzymes including peroxidase (POD) and catalase (CAT). The total chlorophylls chlorophyll $a$ and $b$ contents of the treated fruit were higher than those of the control. The SA immersion did not affect the total carotenoids concentration and TSS whilst it delayed the increase in total sugars and lowered TA content. The fruit softening was delayed by the SA immersion due to the control of soluble pectin increase and insoluble pectin decrease. The antioxidant activity and the concentrations of AsA, TP and TF were enhanced by the SA immersion. The SA immersion also stimulated POD activity but did not induced CAT activity. In conclusion, 2.0 mM SA immersion is an effective postharvest treatment maintaining quality and improving nutritional values of 'Kimju' guava.

Keywords: Guava; Salicylic acid; Bioactive compounds; Firmness; Nutritional quality

\section{INTRODUCTION}

Guava (Psidium guajava L.) is a tropical fruit which belong to the Myrtaceae family. Guava fruit is a rich source of dietary fibre, vitamin $\mathrm{C}$ and bioactive compound including antioxidants (Singh, 2011). In Thailand, many varieties of guava have been commercially grown such as 'Klom Sali', 'Paen Srithong', 'Vietnam' and 'Kimju', which are also exported to neighbour countries such as Singapore and Malaysia (Ruzaina et al., 2013). Guava fruit is commonly classified as climacteric fruit which exhibits ethylene production and respiration rate increment during ripening (Eliane et al., 2005). Although some guava varieties grow in nonclimacteric manner (Azzolini et al., 2005), Thai guava varieties have climacteric manner (Singh, 2011; Silip, 2013).
Guava fruit are commonly consumed at full mature stage with crisp and firm texture. Generally, guava fruit is highly perishable and undergo rapid ripening in 3-4 days at room temperature. Rapid ripening is a main problem affecting quality of Thai guava fruit due to the fruit softening, chlorophyll content decreases and carotenoid content increases, skin brightness decrease, the development of skin browning and rots (Ruzaina et al., 2013). Thus, low-temperature storage is practical way to slow ripening process and minimize postharvest losses where the proper storage temperature for guava fruit must be in the range of $8-15^{\circ} \mathrm{C}$ (Singh, 2011).

Salicylic acid (SA) belongs to phytohormone which classified as a phenylpropanoid compound and stimulated by biotic and

\footnotetext{
*Corresponding author:

Suriyan Supapvanich, Department of Agricultural Education, Faculty of Industrial Education and Technology, King Mongkut's Institute of Technology Ladkrabang, Chalongkrung Rd., Ladkrabang, Bangkok, 10520, Thailand, E-mail: caper4444@hotmail.com
}

Received: 21 July 2017; Revised: 20 September 2017; Accepted: 24 September 2017; Published Online: 02 October 2017 
abiotic stresses to induce defense responses (Supapvanich and Promyou, 2013). Moreover, it is also classified as an ethylene inhibitor (Gerailoo and Ghasemnezhad, 2011). Exogenous SA application has been used to maintain postharvest quality, extend shelf-life, control diseases and alleviate physiological disorders during storage (Asghari and Aghdam, 2010). It is also considered as generally recognized as safe (GRAS) compound for postharvest use (Supapvanich and Promyou, 2013). The optimum dosage of SA non-toxic to plants is in the range of about $0.5-2 \mathrm{mM}$ (Babalar et al., 2007). Many previous works had reported beneficial effects of exogenous SA application on fruit and vegetables. SA could delay ripening process (Srivastava and Dwivedi, 2000), maintain firmness (Promyou and Supapvanich, 2016,), reduce the loss of chlorophyll content (Wei et al., 2011, Supapvanich et al., 2015), alleviate chilling injury (Yang et al., 2012), induce pathogenic resistance (Asghari and Aghdam, 2010) and improve nutritional value by enhancing bioactive compounds and antioxidants (Supapvanich and Promyou, 2013; Asghari and Aghdam, 2010). Thus, SA application might be an effective alternative improving postharvest storability and maintaining quality of guava fruit. Our preliminary work found that SA immersion at the concentration of $2.0 \mathrm{mM}$ maintained good visual appearance and prevented skin browning of 'Kim Ju' guava fruit during cold storage (Mahasub and Supapvanich, 2016). The objective of this study was to evaluate the effect of $2.0 \mathrm{mM} \mathrm{SA}$ immersion on physicochemical quality and bioactive compounds enhancement in 'Kimju' guava during cold storage.

\section{MATERIALS AND METHODS}

\section{Plant materials and specific preparation}

Guava (Psidium guajava) plants cv. 'Kimju' fruit were grown in an orchard at Nakon Nayok province. Fruits were harvested after 100 days of anthesis and delivered to Plant Production Laboratory, Department of Agricultural Education, KMITL within $2 \mathrm{~h}$. Fruits quality and maturity were screened using $a^{*}$ value which was in the range of -17 to -15 and without any physical damage. Afterward, they were rinsed with tapped water two times and air-dried at room temperature. Fruits were divided into two groups; the first group was immersed in water for $10 \mathrm{~min}$ and the second group was immersed in $2 \mathrm{mM} \mathrm{SA}$ for $10 \mathrm{~min}$. After immersion, the fruit were air-dried at room temperature and individual fruits were wrapped with a LDPE film (commercial film for guava) and covered with foam net. The fruit were stored at $12 \pm 1{ }^{\circ} \mathrm{C}, 90 \pm 2 \% \mathrm{RH}$ for 18 days. Three replications ( 3 guava fruits) of each treatment were used to determine pigments, TSS, TA, total sugars, firmness, soluble and insoluble pectins, antioxidant capacity, bioactive compounds including TP, TF, AsA and the activities of antioxidant enzymes such as POD and CAT of the fruit during storage.

\section{The assays of chlorophylls and carotenoids}

A $3 \mathrm{~g}$ of guava fruit skin was homogenized with $20 \mathrm{~mL}$ of absolute ethanol. The homogenized sample was stirred for 15 min and filtered through a Whatman No. 1 filter paper. The sample was rinsed with absolute ethanol four times. The collected solution was adjusted to $100 \mathrm{~mL}$ using absolute ethanol. The absorbances were observed at the wave length of 654, 663 and $470 \mathrm{~nm}$ using Hekios UV-visible spectrophotometer (Thermo Spectronic, Cambridge, UK).

Total chlorophyll and carotenoid contents were calculated as described by Kirk (1968). Chlorophyll $a$ concentration was calculated as $\left(11.75 \times \mathrm{OD}_{645}\right)-\left(2.35 \times \mathrm{OD}_{663}\right)$, chlorophyll $b$ concentration was calculated as $\left(18.61 \times \mathrm{OD}_{645}\right)-$ $\left(3.96 \times \mathrm{OD}_{663}\right)$ and total chlorophylls concentration was then calculated as the sum of chlorophyll $a$ and chlorophyll b. Total carotene was calculated as $[(1000 \times$ OD 470 $)-(2.27$ $\times$ Chlorophyll a $)-(81.4 \times$ chlorophyll b)] $/ 227$. Chlorophyll $\mathrm{a}$, chlorophyll b, total chlorophylls and total carotenoids were expressed in microgram per $\mathrm{g}$ fresh weight $\left(\mu \mathrm{g} \mathrm{g}^{-1}\right)$.

\section{TSS, total sugars and TA contents measurements}

Total soluble solids content was measured by using a hand-held refractometer (ATAGO MNL-112, Japan) and expressed in per-cent $(\%)$. Total sugars concentration was determined according to the method of DuBois et al. (1956). A $10 \mathrm{~g}$ of guava was pulverized and squeezed. $1 \mathrm{~mL}$ of guava juice was adjusted to $50 \mathrm{~mL}$ with distilled water which $1 \mathrm{~mL}$ of diluted sample was mixed with $0.05 \mathrm{~mL}$ of $5 \%$ phenol and $5 \mathrm{~mL}$ of $\mathrm{H}_{2} \mathrm{SO}_{4}$. The sample was left at room temperature for $30 \mathrm{~min}$. Absorbance was recorded at $490 \mathrm{~nm}$ wavelength. Data was expressed in $\mathrm{mg}$ glucose per $\mathrm{g}$ fresh weight. Total acidity of guava fruit was determined using titrimetric method. Five $\mathrm{mL}$ of guava juice was titrated with $0.1 \mathrm{~N} \mathrm{NaOH}$ using $1 \%(\mathrm{w} / \mathrm{v})$ phenophthalene as the indicator. Total acidity was calculated and expressed as the percentage of citric acid.

\section{Firmness measurement}

Fruit firmness was measured at the middle part of the fruit using a TA Plus Texture Analyzer (Lloyds, England) with a $6 \mathrm{~mm}$ cylindrical probe and expressed in $\mathrm{N}$.

The assays of soluble and insoluble pectin substances The acetone insoluble solid (AIS) was prepared by homogenizing guava tissue in acetone as described by Seymour et al. (1987). All enzymes in the AIS was inactivated by adding phenol: acetic acid: water (2:1:1, $\mathrm{v} / \mathrm{v} / \mathrm{v}$ ) solution. The mixture was left at room temperature by $1 \mathrm{~h}$ and filtered through a GF/A filter paper. The 
sample was rinsed with $50 \mathrm{~mL}$ of acetone for three times and dried in a desiccator for 3 days. Approximately $0.05 \mathrm{~g}$ of the AIS was suspended into $20 \mathrm{~mL}$ of $50 \mathrm{mM}$ Ethylenediaminetetraacetic acid (EDTA) consisting of $50 \mathrm{mM}$ sodium acetate, $\mathrm{pH} \mathrm{7}$, solution and then stirred for $6 \mathrm{~h}$ at room temperature. The sample was filtered through a GF/A filter paper and the supernatant was collected. The pallet was re-suspended in $20 \mathrm{~mL}$ of $50 \mathrm{mM}$ sodium carbonate $\left(\mathrm{Na}_{2} \mathrm{CO}_{3}\right)$ consisting of $20 \mathrm{mM}$ sodium borohydride $\left(\mathrm{NaBH}_{4}\right)$ solution and then stirred at $4{ }^{\circ} \mathrm{C}$ for $20 \mathrm{~h}$ followed by $2 \mathrm{~h}$ at room temperature. The sample was filtered through a GF/A filter paper and the filtrate was retained. The both extracts were precipitated using absolute ethanol by making up to concentration of ethanol to $80 \%$. $10 \mathrm{~mL}$ of $1 \mathrm{M} \mathrm{H}_{2} \mathrm{SO}_{4}$ was mixed with the precipitate and the mixture was boiled for $2 \mathrm{~h}$ and then filtered through GF/A filter paper. The hydrolyzate of $50 \mathrm{mM}$ EDTA extracted sample was used to assay soluble pectin and the hydrolyzate of $50 \mathrm{mM} \mathrm{Na}_{2} \mathrm{CO}_{3}$ extracted sample was used to assay insoluble pectin. Both pectin substances were determined using method of Ahmed and Labavitch (1977). The data was presented as mg galacturonic acid (GalA) per g AIS.

\section{Antioxidant capacity, TP and TF assays}

A $3 \mathrm{~g}$ of guava tissue was homogenized with $5 \mathrm{~mL}$ of $80 \%$ (v/v) ethanol and then $15 \mathrm{~mL}$ of distilled water was added. The sample was filtered by using Whatman No.1 filter paper. The filtrate was used to determine antioxidant capacity, total phenols (TP) and total flavonoids (TF) concentrations. Ferric reducing antioxidant potential (FRAP) method which described by Benzie and Strain (1996) was used to determined antioxidant capacity. $0.1 \mathrm{~mL}$ of the extract was mixed with $2.9 \mathrm{~mL}$ FRAP reagent, consisting of acetate buffer $\mathrm{pH}$ 3, $10 \mathrm{mM}$ 2,4,6-tripyridyl-1,3,5-triazine (TPTZ) and $20 \mathrm{mM}$ ferric chloride hexahydrate in the ratio of 10:1:1 $(\mathrm{v} / \mathrm{v} / \mathrm{v})$, and incubated at room temperature for $30 \mathrm{~min}$ for measuring absorbance at $630 \mathrm{~nm}$ wavelength. The data was presented as mmole Trolox equivalents per $\mathrm{g}$ fresh weight $\left(\mathrm{mmol} \mathrm{TE} \mathrm{g}^{-1}\right)$. TP concentration was assayed using the method of Slinkard and Singleton (1977). $1 \mathrm{~mL}$ of the extract was mixed with $1 \mathrm{~mL}$ of $50 \%$ (v/v) Folin-Ciocalteu reagent and then $2 \mathrm{~mL}$ of saturated $\mathrm{Na}_{2} \mathrm{CO}_{3}$ solution was added. The mixture was left at room temperature for at least $30 \mathrm{~min}$ before measuring absorbance at $750 \mathrm{~nm}$ wavelength. The data was presented in term of $\mathrm{mg}$ gallic acid per $\mathrm{g}$ fresh weight $\left(\mathrm{mg} \mathrm{GA} \mathrm{g}^{-1}\right)$. TF concentration was determined using method described by Jia et al. (1999). $1 \mathrm{~mL}$ of the extract was mixed with $3 \mathrm{~mL}$ of distilled water, $225 \mu \mathrm{L}$ of $0.5 \% \mathrm{NaNO}_{2}$. The mixture was left for $6 \mathrm{~min}$ and then $450 \mu \mathrm{L}$ of $10 \% \mathrm{AlCl}_{3} \cdot 6 \mathrm{H}_{2} \mathrm{O}$ was mixed and left for $5 \mathrm{~min}$ and then $1.5 \mathrm{~mL}$ of $1 \mathrm{M} \mathrm{NaOH}$ was added. The absorbance at $510 \mathrm{~nm}$ wavelength was measured. The data was presented as $\mathrm{mg}$ catechin equivalents per $\mathrm{g}$ fresh weight (mg catechin $\left.\mathrm{g}^{-1}\right)$.

\section{Total ascorbic acid assay}

A $3 \mathrm{~g}$ of guava tissue was homogenised with $20 \mathrm{~mL}$ of cold $5 \%$ metaphosphoric acid and then centrifuged at 12000 $x \mathrm{~g}$ for $20 \mathrm{~min}$ at $4{ }^{\circ} \mathrm{C}$. The total AsA concentration was determined according to the method of Hashimoto \& Yamafuji (2001). A $1.6 \mathrm{~mL}$ of the extract was added into $0.8 \mathrm{~mL}$ of $2 \%$ di-indophenol. After that, $1.6 \mathrm{~mL}$ of $2 \%$ thiourea and $0.4 \mathrm{~mL}$ of $1 \%$ dinitrophenol hydrazine were added into the mixture. The mixture was left at $37^{\circ} \mathrm{C}$ for $3 \mathrm{~h}$ and then $2 \mathrm{~mL}$ of $85 \%$ sulphuric acid was mixed, and the mixture was then incubated at room temperature for $30 \mathrm{~min}$. Absorbance at $540 \mathrm{~nm}$ wavelength was measured. Data was expressed as $\mu \mathrm{g}$ AsA per $g$ fresh weight.

\section{POD and CAT activities assays}

A $3 \mathrm{~g}$ of guava tissue was homogenised with $20 \mathrm{~mL}$ of $0.1 \mathrm{M}$ phosphate buffer ( $\mathrm{pH}$ 6.5) containing $0.3 \mathrm{~g}$ of polyvinylpolypyrrolidone (PVPP). The suspension was stirred at $4{ }^{\circ} \mathrm{C}$ for $3 \mathrm{~h}$ and then filtered through a Whatman No. 1 filter paper. The supernatant was held at $4{ }^{\circ} \mathrm{C}$ until be used. G-POD (EC 1.11.1.7) and CAT (EC 1.11.1.6) activities were modified from the method of Andrade Cuvi et al. (2011). The reaction mixture for G-POD assay contained $600 \mu \mathrm{L}$ of $0.5 \%(\mathrm{v} / \mathrm{v})$ guaiacol, $500 \mu \mathrm{L}$ of sample and $1.6 \mathrm{~mL}$ of phosphate buffer ( $\mathrm{pH} 7.0)$. The reaction started when $300 \mu \mathrm{L}$ of $0.059 \mathrm{M} \mathrm{H}_{2} \mathrm{O}_{2}$ was mixed. Enzyme activity was determined by monitoring the increase in the absorbance at $470 \mathrm{~nm}$ wavelength. The unit (U) of G-POD activity was presented in term of $\triangle \mathrm{OD}_{470}$ per min per $\mathrm{g}$ fresh weight. One $\mathrm{mL}$ of reaction mixture for CAT assay contained 0.1 M phosphate buffer ( $\mathrm{pH} 7.0), 0.15 \mathrm{mM} \mathrm{H}_{2} \mathrm{O}_{2}$ and $250 \mu \mathrm{L}$ of the sample. Aliquots of $150 \mu \mathrm{L}$ of the reaction mixture were taken at $0,0.5,1.0,1.5,2.0,2.5$ and $3.0 \mathrm{~min}$ and then added to the test tubes containing $300 \mu \mathrm{L}$ of $0.02 \mathrm{M} \mathrm{TiCl}_{4}$, $200 \mu \mathrm{L}$ of $\mathrm{H}_{2} \mathrm{SO}_{4}$ and $1.35 \mathrm{~mL}$ of distilled water. Absorbance at $410 \mathrm{~nm}$ wavelength was measured. One unit (U) of the enzyme activity was defined as the amount of enzyme consuming of $\mathrm{H}_{2} \mathrm{O}_{2}$ per min per $\mathrm{g}$ fresh weight.

\section{Statistical analysis}

The data was presented as the mean of three replications and standard error (SE) bar. Statistical analysis was carried out using ANOVA and the means compared by the least significant difference (LSD) test at a significance level of $P \leq 0.05$.

\section{RESULTS AND DISCUSSION}

\section{Effects of SA immersion on skin pigments}

The changes in pigments extracted from guava skin such as chlorophyll $a$, chlorophyll $b$, total chlorophylls and total carotenoids content during storage were shown in Fig 1. The loss of greenness and increase in yellowness are known as 
the main problems affecting visual acceptability of guavas. We found that $2 \mathrm{mM} \mathrm{SA}$ immersion enhanced chlorophyll $a$, chlorophyll $b$ and total chlorophylls contents in 'Kimju' guava. We found the marked increases in all chlorophyll compounds during storage for 3 days. Afterward, they were decreased. The total carotenoids content increased in 3 day storage period and then remained constant over the storage. The different change in total carotenoids content between SA immersed and untreated guava fruit were not found. The evidence indicated that $2 \mathrm{mM}$ SA immersion did not affect the total carotenoids change in 'Kimju' guava fruit during cold storage. Meanwhile, total chlorophyll, chlorophyll $a$ and chlorophyll $b$ contents of the guava fruit were induced by SA compared to the control. It is widely acknowledged that exogenous SA treatment retards ethylene biosynthesis and increases chlorophylls in plant (Zhao et al., 1995; Khodary, 2004; Kováćik et al., 2010). Cao et al. (2009) and Zhang et al. (2015) reported that the loss of skin chlorophyll in cucumber fruit was delayed by SA treatment. Furthermore, exogenous SA application maintaining total chlorophyll concentration had been reported for kiwi fruit (Bal and Celik, 2010), asparagus (Wei et al., 2011) and lemon basil (Supapvanich et al., 2015).

\section{Effect of SA immersion on TSS, total sugars and TA contents}

Fig. 2 shows TSS, total sugars and TA contents of 'Kimju' guava during storage. The TSS content of both SA immersed and control fruits seemed constant during the storage (Fig. 2A). We found that SA immersion retarded the increased total sugars content in 'Kimju' guava during storage (Fig. 2B). The total sugars content of the control was increased and reached to the peak on day 9 whereas that of SA immersed fruit remained constant until day 9. Afterward, total sugars content of both SA immersed and control fruits were decreased markedly. The TA content of control fruit was lower than that of $2 \mathrm{mM} \mathrm{SA}$ immersed guava fruit over the storage (Fig. 2C). An increase in TA content was detected in SA immersed fruit during storage for 6 days and then remained constant throughout the storage whilst that of control fruit was slightly increased during 3 -day storage period and then remained constant over the storage. The lower total sugars and higher TA contents of SA immersed fruit suggested that the ripening process was retarded by SA. It is commonly acknowledged that SA is an ethylene inhibitor due to inhibiting ACC synthase and ACC oxidase production as well as their activities (Supapvanich and Promyou 2013). Moreover, both sucrose-phosphate synthase and invertase activities are consequently retarded after the inhibition of ethylene production (Asghari and Aghdam, 2010). The increased TA content in SA immersed fruit might cause the increased citrate efflux by SA as described by Yang et al. (2003). The similar evidence with this work was also reported for 'Bright Pearl' nectarine which $2 \mathrm{mM} \mathrm{SA}$ treatment obviously induced the concentrations of citric acid and total acids in ripe fruit compared to the control

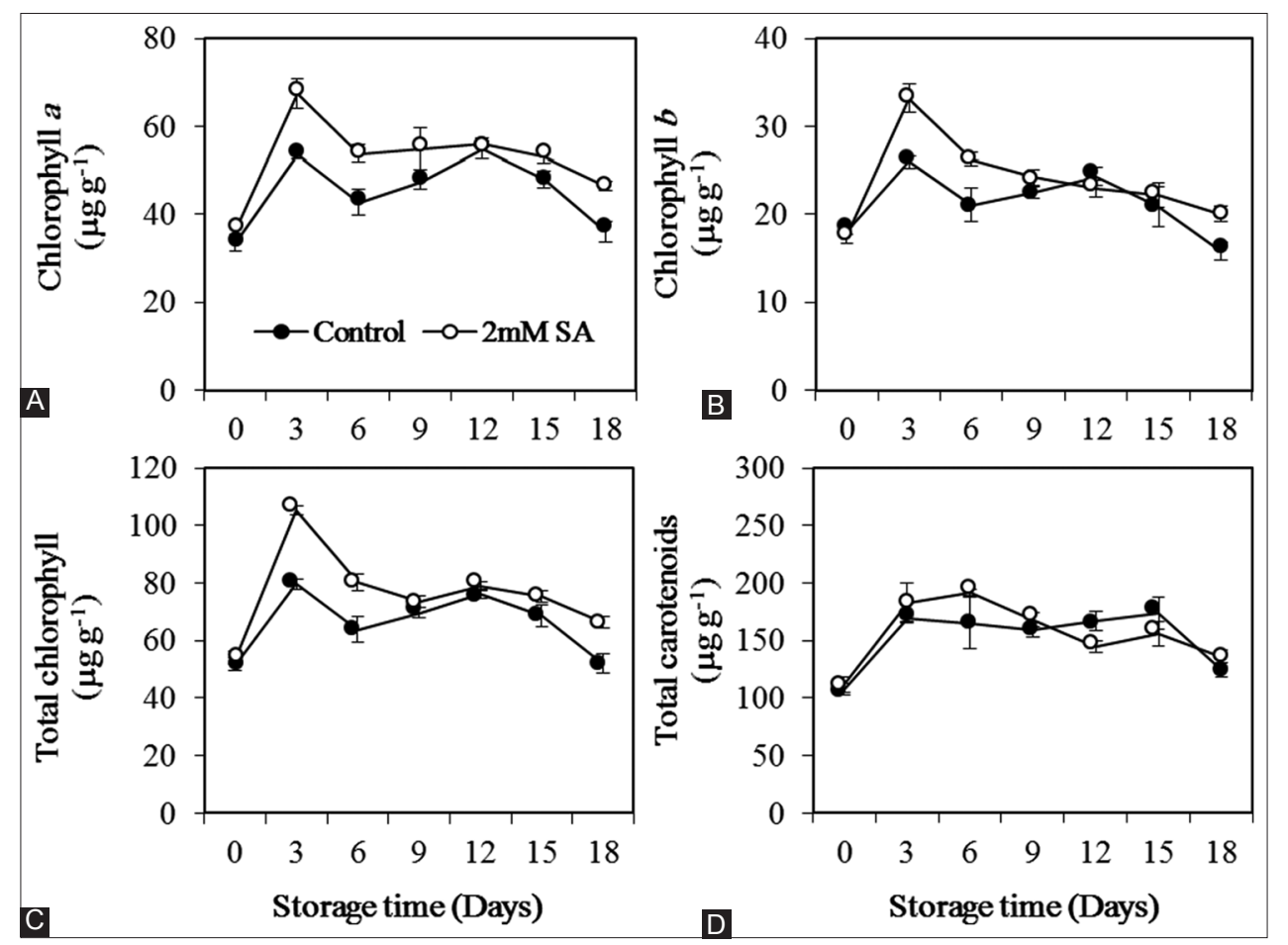

Fig 1. Chlorophyll $a(A)$, chlorophyll $b(B)$, total chlorophylls $(C)$ and total carotenoids $(D)$ contents of 'Kimju' guava fruit immersed with 0 and $2 \mathrm{mM}$ SA during storage at $12 \pm 1{ }^{\circ} \mathrm{C}$ for 15 days. Vertical bar represent SE of the means $(n=3)$. 


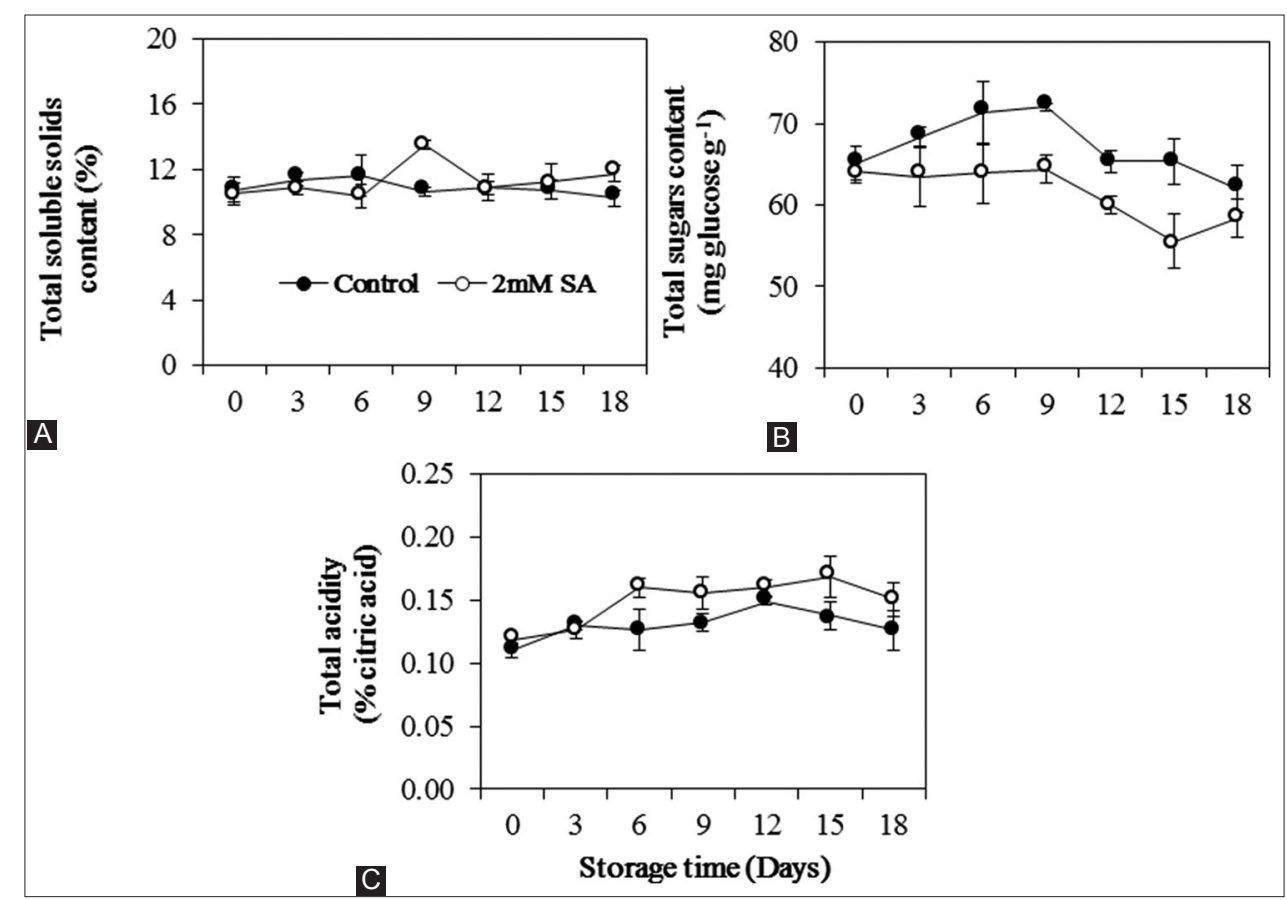

Fig 2. Total soluble solids (TSS) (A), total sugars (B) and total acidity (TA) (C) contents of 'Kimju' guava fruit immersed with 0 and 2 mM SA during storage at $12 \pm 1^{\circ} \mathrm{C}$ for 15 days. Vertical bar represent SE of the means $(n=3)$.

(Azzu, 2016). In wax apple (Sysygium samarangenes), an increase in TA content was also found in preharvest SA treated fruit whereas that of the untreated fruit remained constant over cold storage (Supapvanich et al., 2017).

\section{Effects of SA immersion on flesh firmness and the content of pectic compounds}

The flesh firmness and the contents of both soluble and insoluble pectins of 'Kimju' guava were shown in Fig. 3. The fruit softening was obviously supressed by $2 \mathrm{mM} \mathrm{SA}$ immersion (Fig. 3A). The rapid decrease in firmness of the control was found during 6-day period and then constant over the storage. The pattern of firmness change in SA immersed fruit was similar to that of the control but it was significantly higher than that of the control throughout storage period $(P \leq 0.05)$. The maintained firmness of SA immersed fruit was due to the delay of increased soluble pectin content (Fig. 3B). Soluble pectin content in the control increased rapidly and was significantly higher than that of SA immersed fruit during storage $(P \leq 0.05)$. No significant difference in insoluble pectin content of both SA immersed and control fruits were found during first period of storage. On day 18 of the storage, insoluble pectin content in SA immersed fruit was significantly higher than that of the control $(P \leq 0.05)$. These indicated that SA immersion could delay pectin modification in 'Kimju' guava during storage. In the similar vein, $2 \mathrm{mM}$ SA immersion delayed the increase in soluble pectin and maintained insoluble pectin in 'Kaek Dam' papaya during storage (Promyou and Supapvanich, 2016). The similar result was also reported for peach fruit treated $2 \mathrm{mM} \mathrm{SA}$ (Khademi and Ershadi, 2013). It has been demonstrated that SA retards fruit softening by inducing cell swelling (Zhang et al., 2003), maintaining membrane integrity (Asghari and Aghdam, 2010), inhibiting the activities of cell wall hydrolases (Srivastava and Dwivedi, 2000) and delaying the modification of cell wall components (Supapvanich and Promyou, 2013; Promyou and Supapvanich, 2016).

\section{Effects of SA immersion on antioxidant capacity and bioactive compounds}

Fig. 4 shows the changes in antioxidant capacity, AsA, TP and TF contents in the 'Kimju' guava during storage. The antioxidant capacity, AsA, TP and TF contents of SA immersed fruit were enhanced and higher than those of the control throughout storage. The evidence indicated that SA could improve nutritional quality of guava by inducing the accumulation of bioactive compounds. It had been demonstrated that exogenous SA usage induces defense mechanism in plant by mediating phenylpropanoidflavonoids pathway, which yields phenolic compounds including phenolic acid and flavonoids (Lu, 2009; Asghari and Aghdam, 2010). The enhanced antioxidant potential by exogenous SA application was due to the evaluation of phenylpropanoid-flavonoids pathway (Dokhanieh et al., 2013). Moreover, exogenous SA could enhance dehydroascorbate reductase activity involving the increase in AsA content (Chen et al., 2011). Many previous works also reported that exogenous SA treatment induced the 


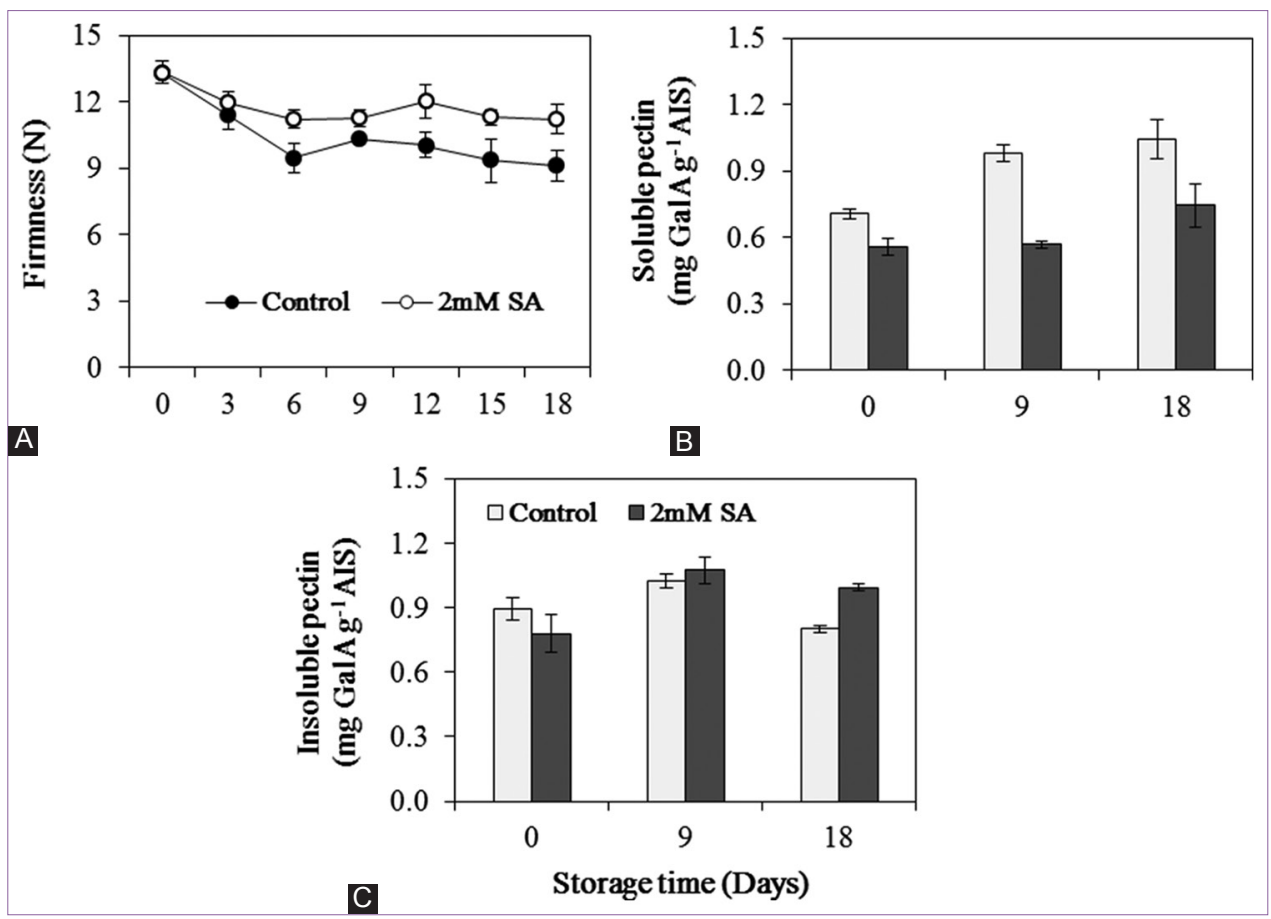

Fig 3. Firmness (A) and the contents of -soluble (B) and insoluble (C) pectins of 'Kimju' guava fruit immersed with 0 and 2 mM SA during storage at $12 \pm 1^{\circ} \mathrm{C}$ for 15 days. Vertical bar represent SE of the means $(n=3)$.

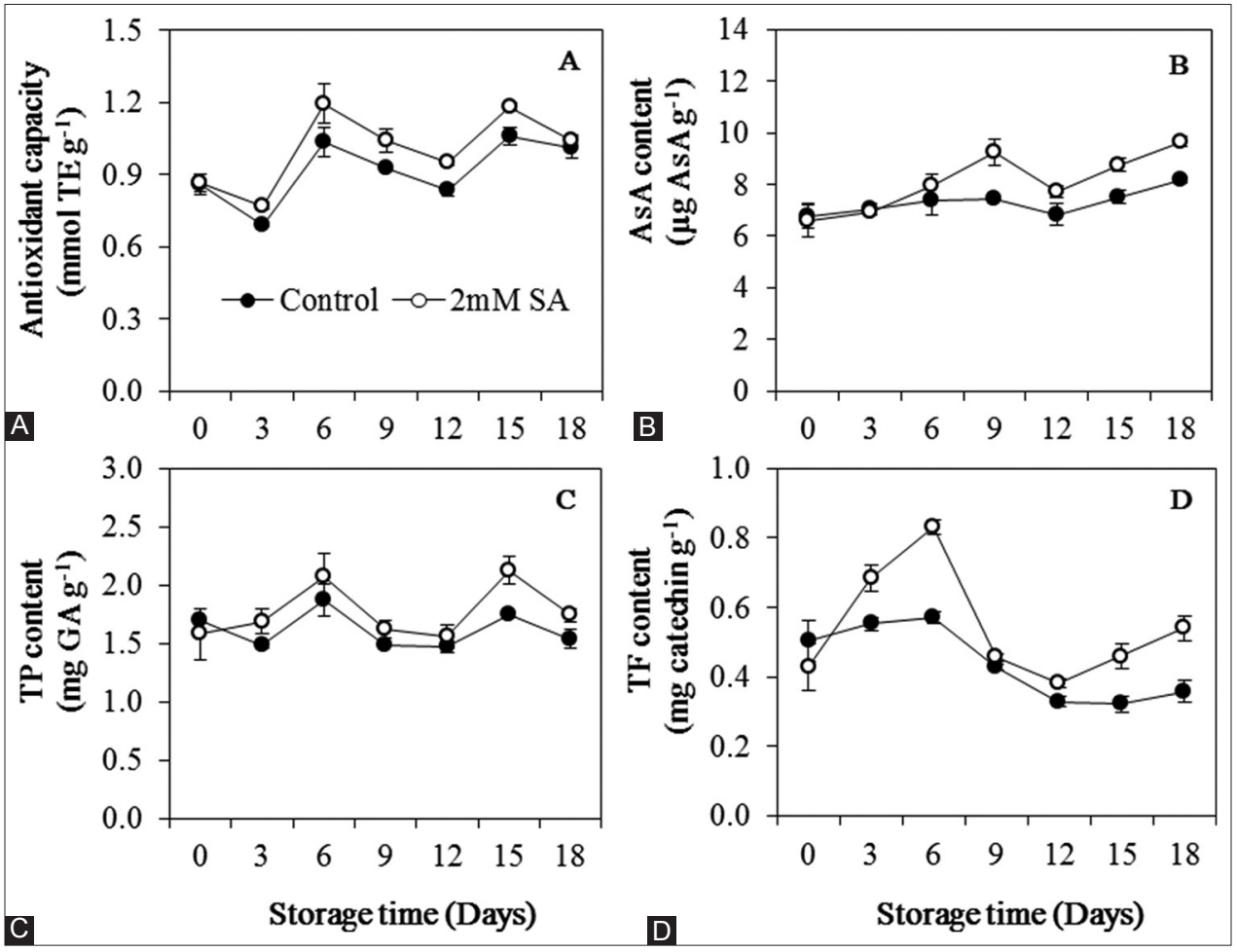

Fig 4. Antioxidant capacity (A), total ascorbic acid (AsA) (B), total phenols (TP) (C) and total flavonoids (TF) (D) contents of 'Kimju' guava fruit immersed with 0 and $2 \mathrm{mM} \mathrm{SA}$ during storage at $12 \pm 1^{\circ} \mathrm{C}$ for 15 days. Vertical bar represent $\mathrm{SE}$ of the means $(\mathrm{n}=3)$.

accumulation of bioactive compounds in cornelian cherry fruit (Dokhanieh et al., 2013), navel orange fruit (Huang et al., 2008), wax apple fruit (Supapvanich et al., 2017) and papaya fruit (Supapvanich and Promyou, 2017).
Effects of SA immersion on the activities of antioxidant enzymes

The effect of SA immersion on the activities of G-POD and CAT of 'Kimju' guava fruit were presented in Fig. 5. 


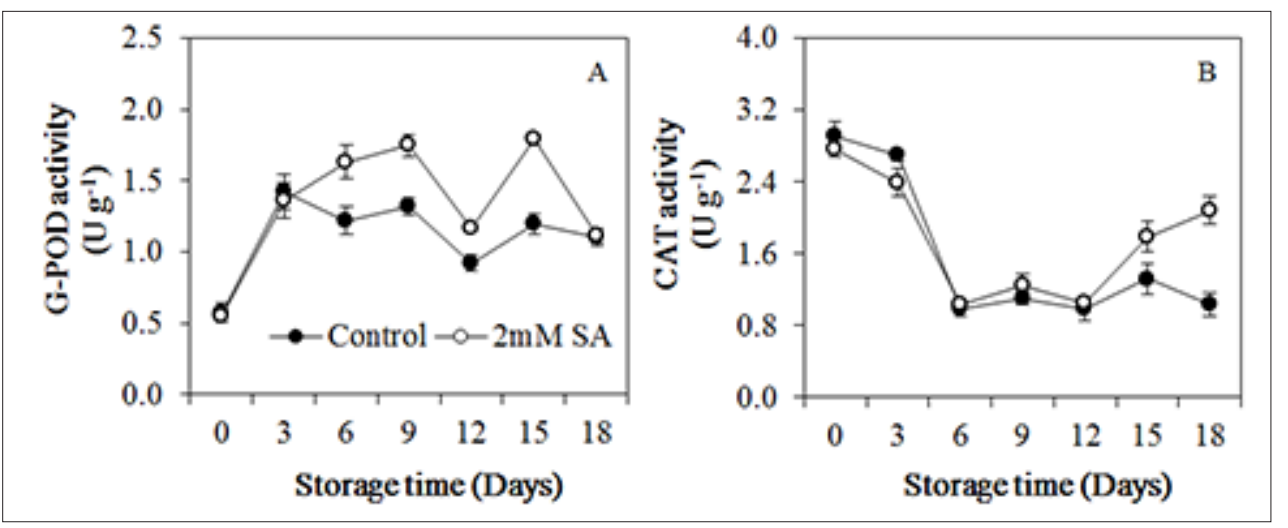

Fig 5. Guaiacol-peroxidase (G-POD) (A) and catalase (CAT) (B) activities of 'Kimju' guava fruit immersed with 0 and 2 mM SA during storage at $12 \pm 1^{\circ} \mathrm{C}$ for 15 days. Vertical bar represent SE of the means $(n=3)$.

G-POD activity increased throughout storage and could be enhanced SA immersion. CAT activity decreased during storage for 6 days and then remained constant until day 12. In this period, CAT activity of both $\mathrm{SA}$ immersed and control fruit were similar. Afterwards, CAT activity of SA immersed fruit was increased and significantly higher than that of control $(P \leq 0.05)$. It is commonly acknowledged that the inducement of defense mechanism in plant by SA is also due to the enhancement of the activities of antioxidant enzymes. Among a range of antioxidant enzymes, PODs constitute an important enzymes involved in numerous processes during plant development and stress response (Passardi, et al., 2005). Mika et al (2010) suggested that SA treatment enhances plasma membrane - bound G-PODs in plant resulting to increase plant tolerance against oxidative stress. Many previous works reported the enhancement of POD activity by exgeous SA application in many kinds of fruit such as navel orange (Huang et al., 2008), peach (Cao et a., 2010), kiwifruit (Kazemi et al., 2011), sweet cherry (Giménez et al., 2016), wax apple (Supapvanich et al., 2017), longan (Suiubon et al., 2017). Unlike, many previous works reported that SA induces CAT activity in many fruits such as wax apple (Supapvanich et al., 2017), pomegranate (Dokhanieh et al., 2016), cucumber (Zhang et al., 2015) and sugar apple (Mo et al., 2008); however, this evidence showed that SA did not induce CAT activity in 'Kimju' guava. This might be due to the forming of SAbinding protein/catalase causing the inhibition of CAT activity as described by Conrath et al. (1995). Furthermore, certain previous studies also reported that exogenous SA application reduced CAT activity and induced POD activity in navel orange (Huang et al., 2008), sweet cherry (Chan and Tian, 2006; Tian et al., 2007) and jujube (Cao et al., 2013).

\section{CONCLUSIONS}

Exogenous SA immersion at $2 \mathrm{mM}$ induced chlorophyll a, chlorophyll b and total chlorophylls contents in guava fruit skin and delayed the increase in total sugars and decrease in TA. SA-immersed fruit had higher firmness than the control which due to lower soluble pectin and higher insoluble pectin contents. Antioxidant capacity, bioactive compounds such as total phenols, flavonoids and ascorbic acid contents and antioxidant enzyme such as POD were enhanced by SA. Interestingly, SA immersion did not induce CAT activity in 'Kimju' guava. 2 mM SA immersion is an effective postharvest treatment for maintaining quality and improving nutritional value in guava fruit.

\section{ACKNOWLEDGEMENTS}

We are thankful to Department of Agricultural Education, Faculty of Industrial Education and Technology, King Mongkut's Institute of Technology Ladkrabang for providing convenience in using scientific instruments, Mr. Y. Kernprie for supporting the guava fruit and Miss P. Mitsang for her technical helps in chemical assays.

\section{Author's contributions}

S. Supapvanich was the project director who planned the overall experiments, interpreted data and wrote this article. B. Mahasap was a master student of Department of Agricultural Education who did experiments and collected data, P. Boonyaritthongchai, C. Techavuthiporn, R. Tepsorn and P. Youryon supervised and helped the results discussion.

\section{REFERENCES}

Ahmed, A. E. R. and J. M. Labavitch. 1977. A simplified method for accurate determination of cell wall uronide content. J. Food Biochem. 1: 361-365.

Andrade, C. M. J., A. R, Vincente, A. Concellón and A. R. Chaves. 2011. Changes in red pepper antioxidants as affected by UV-C treatments and storage at chilling temperature. LWT Food Sci. Technol. 44: 1666-1671. 
Asghari, M. and M. S. Aghdam. 2010. Impact of salicylic acid on post-harvest physiology of horticultural crops. Trends Food Sci. Technol. 21: 502-509.

Azzolini, M., A. P. Jacomino, I. U. Bron, R. A. Kluge and A. Schiavinato. 2005. Ripening of "Pedro Sato" guava: Study on its climacteric or non-climacteric nature. Braz. J. Plant Physiol. 17: 299-306.

Azzu, Y. M. 2016. Modulation of Fruit Ripening, Storage Time and Quality of Fruit with Emulsion of Chitosan Alone and Loaded with Salicylic Acid or Oxalic Acid. PhD Thesis, Curtin University, Australia.

Babalar, M., M. Asghari, A. Talaei and A. Khosroshahi. 2007. Effect of pre- and postharvest salicylic acid treatment on ethylene production, fungal decay and overall quality of Selva. Food Chem. 105: 449-453.

Bal, E. and S. Celik. 2010. The effects of postharvest treatments of salicylic acid and potassium permanganate on the storage of kiwifruit. Bulgarian J. Agric. Sci. 16(5): 576-584.

Benzie, I. F. F. and J. J. Strain. 1996. The ferric reducing ability of plasma (FRAP) as a measure of "antioxidant power": The FRAP assay. Anal. Biochem. 239: 70-76.

Cao, J., J. Yan, Y. Zhao and W. Jiang. 2013. Effects of postharvest salicylic acid dipping on Alternaria rot and disease resistance of Jujube fruit during storage. J. Sci. Food Agric. 93(13): 3252-3258.

Cao, S., Z. Hu., Y. Zheng and B. Lu. 2010. Synergistic effect of heat treatment and salicylic acid on alleviating internal browning in cold-stored peach fruit. Postharvest Biol. Technol. 58: 93-97.

Cao, S. F., Z. C. Hu and H. O. Wang. 2009. Effect of salicylic acid on the activities of anti-oxidant enzymes and phenylalanine ammonia-lyase in cucumber fruit in relation to chilling injury. J. Hortic. Sci. Biotech. 84(2): 125-130.

Chan, Z. and S. Tian. 2006. Induction of H2O2-metabolizing enzymes and total protein synthesis by antagonistic yeast and salicylic acid in harvested sweet cherry fruit. Postharvest Biol. Technol. 39: 314-320.

Chen, S., L. Zimei, J. Cui, D. Jiangang, X. Xia, D. Liu and J. Yu. 2011. Alleviation of chilling-induced oxidative damage by salicylic acid pretreatment and related gene expression in eggplant seedling. Plant Growth Regul. 65(1): 101-108.

Conrath, U., Z. X. Chen, J. R. Ricigliano and D. F. Klessing. 1995. Two inducers of plant defense responses, 2,6-dichloroisinicotinic acid and salicylic acid, inhibit catalase activity in tobacco. Proc. Nat. Acad. Sci. USA. 92: 7143-7147.

Dokhanieh, A. Y., M. S.Aghdam, J. R. Fard and H. Hassanpour. 2013. Postharvest salicylic acid treatment enhances antioxidant potential of cornelian cherry fruit. Sci. Hortic. 154: 31-36.

Dokhanieh, A. Y., M. S. Aghdam and M. A. A. Sarcheshmeh. 2016. Impact of postharvest hot salicylic acid treatment on aril browning and nutritional quality in fresh-cut pomegranate. Hortic. Environ. Biotechnol. 57(4): 378-384

DuBois, M., K. A. Gilles, J. K. Hamilton, P. A. Rebers and F. Smith. 1956. Colorimetric method for determination of sugars and related substances. Anal. Chem. 28(3): 350-356.

Eliane, B., P. J. Angelo, L. P. Ana and A. K. Ricardo. 2005. Delay of ripening of 'Pedro Sato' guava with 1-methylcyclopropene. Postharvest Biol. Technol. 35: 303-308.

Gerailoo, S. and M. Ghasemnezhad. 2011. Effect of salicylic acid on antioxidant enzyme activity and petal senescence in 'Yellow Island' cut Rose flowers. J. Fruit Ornamental Plant Res. 19: 183-193.

Giménez, M. J., M. Serrano, J. M. Valverde, D. Martínez-Romero, S. Castillo, D. Valero and F. Guillén. 2016. Preharvest salicylic acid and acetylsalicylic acid treatments preserve quality and enhance antioxidant systems during postharvest storage of sweet cherry cultivars. J. Sci. Food Agric. 97(4): 1220-1228.

Hashimoto, S. and K. Yamafuji. 2001. The determination of diketo-Lgulonic acid, dehydro-L-ascorbic acid, and L-ascorbic acid in the same tissue extract by 2, 4-dinitrophenol hydrazine method. J. Biol. Chem. 147: 201-208.

Huang, R., R. Xia, Y. Lu, L. Hu and Y. Xu. 2008. Effect of pre-harvest salicylic acid spray treatment on post-harvest antioxidant in the pulp and peel of 'Cara cara' navel orange (Citrus sinenisis L. Osbeck). J. Sci. Food Agric. 88(2): 229-236.

Jia, Z., M. Tang and J. Wu. 1999. The determination of flavonoid contents in mulberry and their scavenging effects on superoxide radical. Food Chem. 64: 555-559.

Kazemi, M., M. Aran and S. Zamani. 2011. Effects of calcium chloride and salicylic acid treatment on quality characteristics of kiwifruit (Actinidia deliciosa cv. Hayward) during storage. Am. J. Plant Physiol. 6: 183-189.

Khademi, Z. and A. Ershadi. 2013. Postharvest application of salicylic acid improves storability of peach (Prunus spersica cv. Elberta) fruits. Int. J. Agric. Crop Sci. 5: 651-655.

Khodary, S. E. A. 2004. Effect of salicylic acid on the growth, photosynthesis and carbohydrate metabolism in salt stressed maize plants. Int. J. Agric. Biol. 6(1): 5-8.

Kirk, J. T. O. 1968. Studies on the dependence of chlorophyll synthesis on protein synthesis in Euglena gracilis, together with a nomogram for determination of chlorophyll concentration. Planta. 78: 200-207.

Kováčik, J., B. Klejdus, J. Hedbavny and M. Bačkor. 2010. Effect of copper and salicylic acid on phenolic metabolites and free amino acids in Scenedesmus quadricauda (Chlorophyceae). Plant Sci. 178(3): 307-311.

Lu, H. 2009. Dissection of salicylic acid-mediated defense signalling networks. Plant Signal Behav. 4: 713-717.

Mahasub, B. and S. Supapvanich. 2016. Effect of salicylic acid treatment on appearance and color of 'Kimju' guava fruit. Songklanakarin J. Plant Sci. 3 Suppl I: 120-125.

Mika, A., M. J. Boenisch, D. Hopff and S. Lüthje. 2010. Membranebound guaiacol peroxidases from maize (Zea mays L.) roots are regulated by methyl jasmonate, salicylic acid and pathogen elicitors. J. Exp. Bot. 61(3): 831-841.

Mo, Y., D. Gong, G. Liang, R. Han, J. Xie and W. Li. 2008. Enhanced preservation effects of sugar apple fruits by salicylic acid treatment during postharvest storage. J. Food Sci. 88(15): 2693-2699.

Passardi, F., D. Longet, C. Penel and C. Dunand. 2005. Peroxidases have more functions than a Swiss army knife. Plant Cell. Rep. 24: $255-256$

Promyou, S. and S. Supapvanich. 2016. Effects of salicylic acid immersion on physicochemical quality of Thai papaya fruit 'Kaek Dam' during storage. Acta. Hortic. 1111: 105-112.

Ruzaina, I., A. R. Norizzah, M. S. H. Zahrah, C. S. Cheow, M. S. Adi, A. W. Noorakmar and A. M. Zahid. 2013. Utilization of palmbased and beeswax coating on the postharvest-life of guava (Psidium guajava L.) during ambient and chilled storage. Int. Food Res. J. 20(1): 265-274.

Seymour, G. E., S. E. Harding, A. J. Taylor, G. E. Hobson and G. Tucker. 1987. Polyuronide solubilization during ripening of normal and mutant tomato fruit. Phytochemestry. 26: 1871-1875.

Silip, J. J. 2013. Quality Characteristics of Guava (Psidium guajava L. cv. Kampuchea) in Response to Hydrocooling, Time, Storage, Temperature, and Storage Duration, MS. Thesis. University Putra Malaysia, Malaysia. 
Singh, S. P. 2011. Guava (Psidium guajava L.). In: Yahia, E. M. (Ed.), Postharvest Biology and Technology of Tropical and Subtropical Fruits, Woodhead Publishing Limited, Cambridge, United Kingdom. pp. 213-245.

Slinkard, K. and V. L. Singleton. 1997. Total phenol analysis: Automation and comparison with manual methods. Am. J. Enol. Vitic. 28: 49-55.

Srivastava, M. K. and U. N. Dwivedi. 2000. Delayed ripening of banana fruit by salicylic acid. Plant Sci. 158: 87-96.

Suiubon, S., S. Supapvanich and S. Promyou. 2017. Postharvest quality maintenance of longan fruit by ultra violet-C incorporated with salicylic acid application. Emirates J. Food Agric. 29(3): 179-187.

Supapvanich, S., P. Mitsang and P. Youryon. 2017. Preharvest salicylic acid application maintains physicochemical quality of 'Taaptimjaan' wax apple fruit (Syzygium samarangenese) during short-term storage. Sci. Hortic. 215: 178-183.

Supapvanich, S., R. Phonpakdee and P. Wongsuwan. 2015. Chilling injury alleviation and quality maintenance of lemon basil by preharvest salicylic acid treatment. Emirates J. Food Agric. 27(11): 801-807.

Supapvanich, S. and S. Promyou. 2013. Efficiency of salicylic acid application on postharvest perishable crops. In: Hayat, S. and A. A. M. Alyemei (Eds.), Salicylic Acid: Plant Growth and Development, Springer, New York, USA. pp. 339-355.
Supapvanich, S. and S. Promyou. 2017. Hot water incorporated with salicylic acid dips maintaining physicochemical quality of 'Holland' papaya fruit stored at room temperature. Emirates J. Food Agric. 29(1): 18-24.

Tian, S., G. Qin, B. Li, Q. Wang and X. Meng. 2007. Effects of salicylic acid on disease resistance and postharvest decay control of fruits. Stewart Postharvest Rev. 6: 1-7.

Wei, Y., Z. Liu, Y. Su, D. Liu and X. Ye. 2011. Effect of salicylic acid treatment on postharvest quality, antioxidant activities, and free polyamines of asparagus. J. Food Sci. 76: 126-132.

Yang, Z. M., J. Wang, S. H. Wang and L. L. Xu. 2003. Salicylic acidinduced aluminium tolerance by modulation of citrate efflux from root of Cassia tora L. Planta. 217: 168-174.

Zhang, Y., M. Zhang and H. Yang. 2015. Postharvest chitosan-gsalicylic acid application alleviates chilling injury and preserves cucumber fruit quality during cold storage. Food Chem. 174: 558-563.

Zhang, Y., K. Chen, S. Zhang and I. Ferguson. 2003. The role of salicylic acid in postharvest ripening of kiwifruit. Postharvest Biol. Technol. 28: 67-74.

Zhao, H. J., X. W. Lin, H. Z. Shi and S. M. Chang. 1995. The regulating effects of phenolic compounds on the physiological characteristics and yield of soybean. Acta. Agron. Sin. 21: 351-355. 